\title{
The Functions of Past Tenses: Greek, Latin, Italian, French
}

\author{
Ernst Pulgram \\ The University of Michigan
}

\begin{abstract}
Latin grammarians describing their language (or laying down rules for the proper use of it) owe much to their Greek predecessors, notably Dionysius Thrax (c. 170-90 B.C.), whose rules they sought to replicate and whose terminology they translated. But since Latin is different in structure from Greek, and since in particular it does not have the same number of past tenses as Greek, the syntax of its tenses is not congruent with that of Greek either. And if the names of Greek tenses indicated in some measure, however awkwardly, their function, translation of these names into Latin could not but be misleading. Since also modern grammarians often base themselves on this Graeco-Roman grammatical tradition, the rules for the use of tenses and the names they devised in imitation of that tradition are less than satisfactory and at times confusing, whether they pertain to the temporal or the so-called aspectual function of the past tenses.

It is argued that language in general, and tenses in particular, do not always or necessarily present faithfully the physical reality but rather re-present it, filtered, as it were, through the speaker. In this manner, the use of one or the other past tense evokes that perception of the action expressed by the verb which the speaker wants the hearer to receive. It follows that the same reality can be stated by, say, either the "imperfect" or the "past" (simple or compound) in Italian or French, depending on whether the speaker wishes to have the hearer contemplate what goes on as a picture (though movement may be involved), or whether he wants to report to the speaker the occurrence of an event, or of a series of events. In the first case, the verb answers the question - posed or implied - "What was the state? What were the circumstances?"; in the second, the question is "What happened? What happened next?".
\end{abstract}

The seemingly odd juxtaposition of languages in my title has two reasons. First, I found it necessary to go back to the ancient grammarians, especially the Greeks, in order to account for the statements on the past tenses one finds in modern analytic and didactic writings: for it is upon the nomenclature and the rules which the Greeks devised for their language that Latin grammarians and their successors over the centuries based their theories and precepts, some deliberately and some 
only in uncritical deference to tradition. Second, I chose to pursue my inquiry diachronically because of my conviction that for the understanding of synchronic facts - not only of language but of most things for which we seek an explanation in addition to a description - it is of the essence to find out how, and if possible why, these facts came to be as they are. This sounds like, and in fact is meant to be, an encomium of history that stresses the benefit, indeed the necessity, of looking historically at a world and a universe where nothing ever stands still.

My principal theses will be the following. (1) The functional and semantic description of past tenses in Greek by Greek grammarians had to become inapplicable if simply transferred, first to Latin and thence to modern languages, for the simple reason that rules cannot be assumed to be identical for differently structured languages. (2) It is true that the tenses refer not only to the time at which but often also to the manner in which an action takes its course (the latter is generally called the aspectual facet of tense forms); I shall argue, however, that tenses are also employed so as to evoke in the hearer a picture of the action as the speaker intends him to perceive it, whether or not it corresponds to temporal or aspectual reality, implying the possibility of expressing, at the choice of the speaker, the same real action or event by one of several available tenses. If the purpose of tense in the first mode is to PRESENT reality, that in the second is to RE-PRESENT reality as filtered through the speaker. This twofold attitude of speech toward reality will be stressed throughout my argument. (I disregard - as I may in the present context - the epistemological problem of "reality" and follow Vaihinger's theory that we cannot but act - and speak - as if we knew and dealt with reality.)

I shall not pursue that will-o'-the-wisp "universality", certainly not on the basis of the few Indo-European idioms I know and can talk about with some competence. And I shall forego rummaging for supportive evidence, which a modicum of industry cannot fail to discover, in other people's descriptions of languages of which I know nothing, and of which, in more cases than is good for all of us, the describers themselves did not know anywhere near enough. I may, however, venture some generalities concerning the languages I discuss, and perhaps concerning the larger linguistic family of Italic - Latin - Romance, possibly IndoEuropean, to which they belong.

The questions I shall raise are syntactic and semantic rather than morphological: What do past tenses do in a sentence, or in a text, what is their function, how does the speaker intend them to be understood and how does the hearer understand them - in short, what is their meaning? ${ }^{1}$ Inevitably the notion of aspect will intrude. An eminent researcher on aspect came to the somewhat disheartening conclusion: ". . a after seventeen years I have found myself peculiarly uninterested in whether or not I have exhausted the subject [of time, tense, and aspect]. The subject has exhausted me" (Bull 1968: v-vi). Indeed the bibliography on aspect is 
enormous, it is in fact inexhaustible, and surely exhausting. I have no intention of rehearsing it all in the pages that follow, not because I believe (as of course I do not) that careful research in the works of one's predecessors is unnecessary, but rather because much of what has been written about aspect is curiously repetitive and monotonous, nothing more than variations on the same theme. ${ }^{2}$ The recurrent adjectives referring to the aspectual function of tenses are: durative, finished/ completed, unfinished/noncompleted, customary, repetitive, momentary, etc. It is astonishing that even structurally and genetically unrelated languages which share no, or few, other features, are alleged to possess the same aspectual properties. Even though all speakers belong to the same biological species and perceive more or less the same world, the differentness of their languages makes one wonder why such uniformity with respect to aspects should be thought to prevail. One reason for this unusual unanimity lies, as I have already suggested, in the use of the same sources, namely, the ancient grammarians, notably and ultimately the Greeks. But the question has to be asked how these ancient grammarians themselves developed their terminology and their opinions, and how and why later authors, down to modern prescriptive grammarians and descriptive linguists, came to adopt them.

Let us begin with Italian, and then move backward. Grammars list the following three past tenses (I omit those expressing relative pastness, the pluperfect and the future perfect): imperfetto (cantava), passato prossimo or perfetto (ha cantato), and passato remoto or preterito (canto) ${ }^{3}$ The most naive way of explaining the use of these tenses relies on the meaning of their names: the imperfetto, continuing also morphologically the Latin imperfectum, which literally means 'incomplete', is said to describe an action unfinished in the past, the passato prossimo or perfetto (cf. Latin perfectum 'finished') an action finished in the near past, and passato remoto or preterito an action finished in the distant past. (It should be noted, however, that it is not the Italian perfetto/passato prossimo that continues morphologically the Latin perfectum, but the preterito/passato remoto. The cause of this non-congruence of terms - and, as will be seen presently, of functions - lies in the fact that Latin has but two past tenses and Italian three.) But this is far too simple a statement, and obeying rules based on these names will not produce unfailingly correct Italian sentences.

Of course, more sophisticated rules have been formulated. I shall quote below those proposed by Lepschy and Lepschy, native spcakers of Italian and respected linguists, together with some general statements representing a consensus, and some from other sources. I fear, however, that all these descriptions and prescriptions are somewhat confusing and contradictory. They cannot but raise questions in the thoughtful learner of Italian and in the non-native speaker who has not yet acquired a "feel" for the language. 
IMPERFIETTO. "The imperfect is used ... for action (in the subordinate clause) during which something else goes on or happens (in the main clause). If the action in the main clause is continuous, it is expressed in the imperfect ... The imperfect is used for cumpleted action if this is habitual ... Habitual action within a completed period of time is however in the past historic [= passato remoto] ... The imperfect is the tense normally used for descriptions...." (Lepschy and Lepschy 1977: 221-2).

This represents the consensus of most grammarians concerning the functions of the imperfetto: duration, description (of action in progress and of state), repetition, habitualness (but notice the habitual action within a completed period that is not served by the imperfetto), narration. ${ }^{4}$ It is also observed that "some verbs are more frequently used in the imperfect [than in the other past tenses] : sapeva bene il latino 'he knew Latin well', non capiva la musica 'he did not understand music', sembrava stanco 'he seemed tired', non credeva in Dio 'he did not believe in God" " (Lepschy and Lepschy 1977: 222). ${ }^{5}$ But since in these phrases the verb expresses a condition, a state - respectively, knowledge of Latin, incomprehension of music, appearance of tiredness, disbelief in God - the imperfetto fits well among the functions referred to earlier.

PASSATO REMOTO. "The past historic [= passato remoto] is the past tense used for complete action which is no longer related to the present ... It is thus the tense normally used for the action in a narrative set in the past" (Lepschy and Lepschy 1977: 220-1). But if that is all that needs to be said about the passato remoto, then rendering in this tense the phrases cited at the end of the description of imperfetto - seppe il latino, non capi la musica, sembrò stanco, non credè in Dio - would indicate that the action "is no longer related to the present"; but this is not necessarily true. Also, one could terminate many passato remoto phrases with un momento prima 'an instant earlier', which leads one to wonder about the notion of the distant past often connected, even in its name, with the passato remoto (though this is implicitly rejected by the Lepschys, who say that "lo vidi passare 'I saw him go by' may refer to an event of a short time before"). Hence some grammarians have variously called this tense past historic, past absolute, preterite, passato semplice 'simple (i.e., noncompounded) past'.

PASSATO PROSSIMO. "The perfect [=passato prossimo] is used to describe a completed action which is still felt to be in some way linked to the present ... What is relevant is not so much the period of time which has elapsed as whether the event is felt to be related to the present... It is of course natural that the perfect should often be used for recent events ... but one can also have examples [with the passato remoto] for an event of a short time before... The perfect is also used to describe an action happening within a span of time which, however far back it began, is not yet concluded.. It is also used to describe past events 
the effect of which still lasts ... (Lepschy and Lepschy 1977: 220). This, too, expresses rather a consensus on the nature and function of the passato prossimo. But I must point out here an important trait of this statement: while it repeatedly refers to the objective reality of the event -. its completion, its possible nearness to the present, indeed aiso its possible non-completion under certain circumstances - it does contain twice the phrase "felt to be," which involves, not objective reality, but the way the speaker "feels" reality and the way in which, therefore, the hearer is asked to perceive it. My own conclusion is - and I have alluded to this at the beginning - that it is often the manner in which reality is "felt" by the speaker, and the manner in which he wants the hearer to perceive it, and not objective reality as such, that determines the use of one or the other past tense. I called this the re-presentative function of language.

In his descriptive grammar, Hall rejects the traditional names for the tenses of the past, for good morphological and functional reasons. The imperfetto is renamed Passato $\mathrm{A}$, and the passato remoto is Passato $\mathrm{C}$. "La differenza ... sta nell'aspetto. Il Passato $\mathrm{C}$ si riferisce a uno stato di cose con un cominciamento specificabile e una fine anch'essa specificabile, e che non è durato fino al momento attuale; il Passato A, invece, a uno stato di cose il cui cominciamento e la cui fine non hanno nessun' importanza ..." (Hall 1971: 86). 'The difference ... is one of aspect. The Passato $C$ refers to a condition with a specifiable beginning and a specifiable end, which has not lasted to the present moment; the Passato A, however, to a condition whose end and beginning have no importance ...'(Hall 1971: 86). (The passato prossimo is treated under the heading locuzione 'phrase', and its function in Hall's terms will be discussed below.) I submit that here, too, both the objective reality and the speaker's attitude toward reality are promiscuously set up as defining criteria: reference is made to actual duration, but the terminals are named "specifiable" rather than specified, and their importance rather than their actuality is made an issue. This mixture, I believe, beclouds the description of the function of the tenses.

I find the same slight but significant wavering between presentation and representation of reality in Migliorini's grammar for use by Italian highschool students. In the following rules I have marked with parenthetical [N.B.] the places where attitude, or subjective view of reality, is revealed by a form of the verb considerare 'to view'. "L'imperfetto indica un'azione passata considerata [N.B.] nella sua durata. ... Altre volte esso indica azione ripetuta. . . Esso è adoperato specialmente nelle descrizioni e narrazioni." "The imperfetto indicates a past action viewed [N.B.] in its duration ... At other times it indicates repeated action ... It is used especially in descriptions and narration.' "In genere si può dire che il passato remoto indica un fatto avvenuto nel passato lontano o anche vicino senza che se ne consideri [N.B.] la relazione con il presente ... Invece il passato prossimo 
indica un fatto che si considera [N.B.] in relazione con il presente per le sue conseguenze ..." 'In general one may say that the passato remoto indicates a fact that occurred in the distant past, or also in the near past if one does not view [N.B.] its relation to the present ... The passato prossimo, however, indicates a fact which is viewed [N.B.] in relation to the present as regards its consequences ...' (Migliorini 1948: 128). Of course, this text is written for native speakers of Italian, whose Sprachgefühl for their language is a sufficiently reliable guide for their speech.

It is only natural that these inherently difficult rules, somewhat ambiguous and murky even if phrased by masters of the trade, become even more intractable if less experienced authors and pedagogues try to condense and "simplify" them in textbooks for the benefit of language learners. I shall cite some examples from one such source. ${ }^{6}$ "The imperfetto ... is used to describe habitual actions in the past ..., actions in progress in the past, when something also happened or something else was going on .... [It is used] to describe physical, mental, and emotional states." "The passato composto [= passato prossimo] narrates events completed in the past. It tells what happened at a given moment." "The passato semplice [= passato remoto] ... is a tense reporting an action completed in the past." Perhaps such brief quotations do an injustice to the author; but the following passage explaining the difference between the compounded and the simple past provides no relief: "There is no difference in meaning between the passato composto and the passato semplice. Both express a past action, but there are differences in usage. If the action occurred in the past (last year, three months ago, the other day) and is completely finished, that is, has no reference to the present, the passato semplice is used .... If the action took place during a period of time which is not yet over (today, this month, this year) or if the effects of the action are continuing into the present, the passato composto should be [N.B.] used." If all that confuses the student - as it must, no matter what his age - his perplexity can only be increased by the following partial withdrawal of the rules stated earlier: "Those are formal rules, but in modern Italian the passato semplice is seldom used in conversation, except in certain areas of the country. However, it is commonly used in writing ... The passato composto is the tense used in spoken Italian to express a past action with or without reference to the present." Surely behind all this lies an Alicesyndrome. When the heroine of Alice in Wonderland was asked by the caterpillar for a clearer explanation, she had to admit her weakness: "I am afraid I can't put it more clearly ... for I can't understand it myself, to begin with."

The somewhat garbled and half-hearted statement on the equivalence in Modern Standard Italian of the passato prossimo and passato remoto conceals two types of dialectal circumstances, one of local and one of social order. These have to be understood before the use of tenses can be stated in reasonable linguistic terms. ${ }^{7}$ 
In the Standard Italian spoken north of Tuscany, the compounded past, having virtually replaced the simple past, is now the only past tense used in colloquial and formal speech beside the imperfect. ${ }^{8}$ In some regions this is probably due to the absence of forms of the simple past in the local dialects, which is bound to be reflected in the regional standard of Venezia, Lombardy, Liguria, and Piedmont (cf. De Mauro 1970: 170, 384-5). But in addition to such influence from the local dialects, a powerful cause for the rise of the compounded past has been the pervasive tendency to replace synthetic (non-compounded) by analytic (compounded) verb forms, which has been active in Italian, and in Romance (and indeed other IndoEuropean languages) in general, for the past millennium. ${ }^{9}$

In apparent opposition to the trend just mentioned is the preference for the simple past over the compounded past in the Standard Italian spoken in the southern provinces of Italy and in Sicily, where the compounded past is, in some areas, almost unknown. ${ }^{10}$ Some have regarded this phenomenon as the stubborn survival of the Latin (synthetic) perfectum, which somehow in those southern areas did not succumb to the widespread replacement by the compounded past. Possibly more persuasive is the hypothesis that the usage is due to the influence of Greek, once widely used in the south of Italy and still surviving in some speech islands, whose (synthetic) aorist is continued in the (synthetic) simple past in both the local dialects and the southern variety of Standard Italian. ${ }^{11}$

In Central Italy, especially in Tuscany, the simple and the compounded past are used with the same function and express the same meaning, but the latter is steadily gaining ground, except in formal writing style. Since the regional standard speech of Tuscany is generally regarded as Standard Italian par excellence, educated Tuscans, and with them prescriptive grammarians and teachers of Italian, consider the simple past as more formal than the compounded past in cases where in less formal speech the latter may replace the former. For those preoccupied with prestigious and correct speech, formality virtually implies good quality, hence the simple past is also "better" than the compounded past. Thus, the existing complexity of regional standard usage, as shown by the contrast between north and south just described, is aggravated by social considerations, indeed anxieties, on the part of those who wish to speak and teach the "best" Italian.

In today's Italy, the centers of cultural, political, industrial, and financial gravity lie undoubtedly in the north; the central Italian regions of Tuscany, Emilia, and Umbria may take pride in past glories, especially the Renaissance, rather than in present accomplishments; and the south, all the way from the Abruzzi to Sicily, is regarded as somewhat backward, poor, indolent, ignorant, and in some ways corrupt. Rome with its surroundings is, in the midst of all this, an anomaly: it is the political capital of the nation and the seat of its parliament, it was indeed the capital of the mighty Roman empire of antiquity, it is the capital of the Roman 
Catholic church (the City of the Vatican is, in all but administrative aspects, an integral part of Rome), it harbors an enormous and not too highly esteemed bureaucracy, it has an opera, theaters, museums, and various other appurtenances of the "cultural life"; but despite all that, Northerners see it rather as a southern town, with all the shortcomings and derogation this classification implies. Such is the usual assessment of Italians by Italians. Whether or not this opinion reflects real social facts is sociolinguistically, as regards the judgment by Italians of their various dialects and their divergent ways of speaking Standard Italian, irrelevant: it is belief, not truth, that determines the speakers' attitude toward speech (and, for that matter, toward a lot of other things) in Italy and elsewhere.

The speaker's quandary is, then, that the feature of language which is judged prestigious and "good" by the guardians of linguistic propriety, namely, the simple past, is associated with the speech of the allegedly scrubby, yokelish, and somnolent south, whereas the wizards and hustlers of the north, who appear to possess a forward-looking and modern culture in both the material and spiritual domain, are the ones who have practically abolished the simple past in favor of the compounded past - except perhaps on those occasions when they consciously, and self-consciously, obey their admittedly stodgy school grammars.

Given all these in part contradictory and in part overlapping conditions of local and social dialects, one must conclude that with regard to the use of these two past tenses Italians are caught in an uneasy dilemma; a speaker is not unlikely to be censured, albeit from different sources, whether he employs, under certain circumstances, the simple or the compounded past. This is, however, but one of the linguistic uncertainties that became endemic in Italy with the Questione della lingua. This controversy had its beginnings in the time of Dante with the problem as to what kind of speech, after the demise of Latin as a viable means of communication, should be adopted, and in some of its ramifications it has not been settled to this day. The catch phrase Lingua toscana in bocca romana not only is meaningless, since it sets an unrealizable goal, but also completely disregards the speech of the north where, as mentioned, numerous aspects of the national life and identity of the modern state are clustered.

The trend currently to be observed, however, is the one toward universal acceptance of the compounded past in the place of the simple past - which implies a degree of de-Tuscanization of the Modern Standard Italian speech. ${ }^{12}$ Before this stage is reached, there will occur a period of totally free variation, where such rules on the use of these two tenses as I had occasion to discuss will be antiquated and inoperative - which they already are in the colloquial speech of a great many Italians of all social classes. In part, at least, these rules will lose their credibility and efficacy because of their inherent vagueness and opacity. ${ }^{13}$

In Modern Standard French, the simple and the compounded past tenses (passé 
simple and passé composé, whose infelicitous names passé défini and passé indéfini, respectively, still hang on, precariously but still misleadingly) are nowadays regarded by all grammarians as serving identical syntactic and semantic ends, the difference being only in the degree of formality: the simple past is more formal, more literary than the compounded, with the latter all but universal in oral performance, excepting a highly solemn or oratorical one. French thus has already reached a stage that Italian is still moving toward. But the directions for use of the two French tenses which appear in older grammars, or even in recent but very conservative ones, resemble those I have cited for Italian. ${ }^{\mathbf{1 4}}$ Both tenses are contrasted with the imparfait, whose rules for employment are also couched in terms remarkably similar to those allegedly governing the use of the Italian imperfetto.

Eventually I shall propose a different view of these matters of "aspect" in Italian and French. For the moment, however, consider that in the following sentences all three past tenses in each of these two languages deliver intelligibly and correctly a statement about God's creation of the world, that is, about the same event (whether real or mythical is irrelevant here):

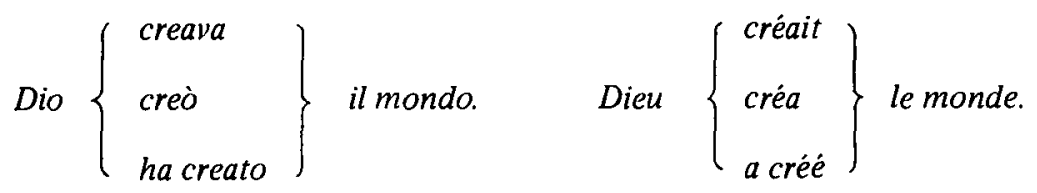

It does seem to follow that it is not reality itself that necessarily governs the use of these tenses, and it is from this perception that my argument will proceed. But now I shall attempt to show how the Italian (and French) rules on the past tenses came to be the way they are, as I promised at the outset. To do this I must go back to the second century B.C., to the fountainhead of grammatical lore for centuries to come, including even our own, to Dionysius Thrax, who lived from about 170 to 90 B.C. He was a pupil of the famous Aristarchus of Samothrace (c. 217 to 145 B.C.), styled $\delta$ $\gamma \rho \alpha \mu \mu \alpha \tau \imath k \omega \tau \alpha \tau \circ S$, which is literally the superlative of 'grammarian' and may be freely translated as 'the grammarians' grammarian'.

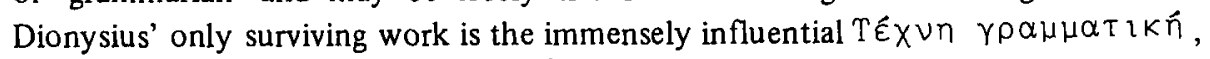
or Ars grammatica, or just 'Grammar'. 15

In Dionysius (in the commonly used edition by Uhlig, now a century old) the discussion of tenses receives but four lines, in which not a word is said about their syntax. But their names are carefully designed so as to portray their function. Here, then, the explanation of function derived from the name does make good sense (which it does not, as I noted, for some of the Italian and French terms). This is so because the Greek terms were invented to contain an explanation of the purpose of what they named; the modern terms, however, are for the most part 


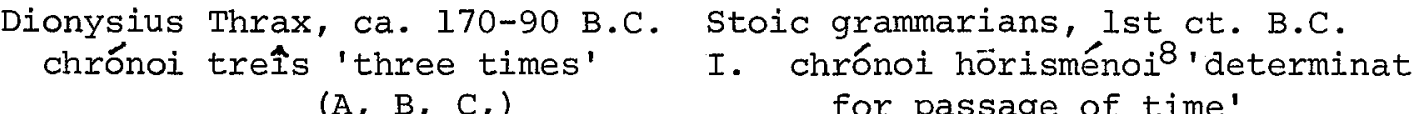

(A) reference to past time (b) terminal implied

(c) terminal implied

$\left.\begin{array}{l}\text { (B) } \text { (a) reference to } \\ \text { (b) } \\ \text { (c) } \\ \text { (d) }\end{array}\right\}$ as above

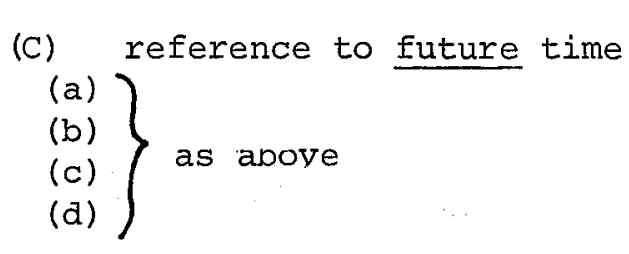

1 cf. elélutha (perf.) 'to walk' cf. parateíno 'to extend (itself)' cf. parákeimai 'to be available'
cf. télos 'end, boundary'

cf. hóros 'boundary' diaphorai téssa, $(A, C)$ 'four distinctions' $(a, b, c, d)$

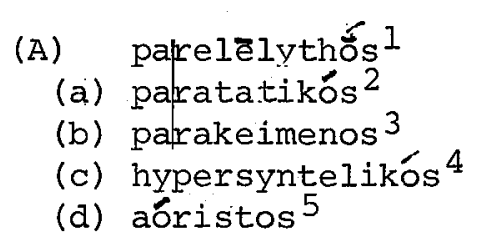

$$
\text { 1) paratatikós } 2
$$

II. chrónoi aóristoi 5 'indeterminate for

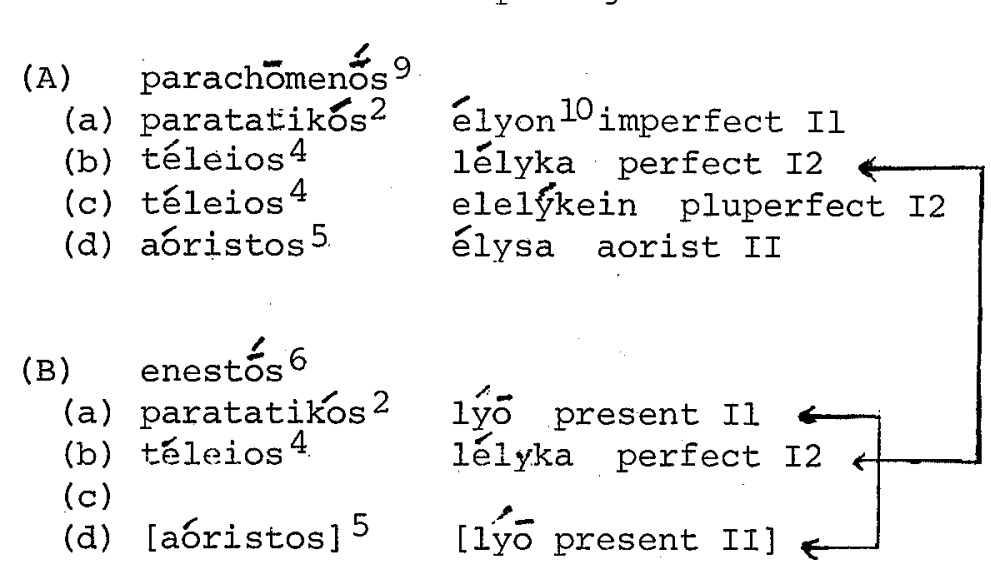

(B) enestốs 6

(a)
(b)
(c)
(d)

(c) mél1ōn 7
(a)
(b)
(c)
(d)

(c) mé11ōn 7
(a)
(b)
(c) [áristos] 5 lýsō future II
(d) [aór

6 enístemi 'to be present
7 mél1ōn 'future' (adj.)

8 hốra 'period of time!

9 paroíchomai 'to have passed by'
Varro, $116-27$ B.C.
viii. $20:$ temporal

vili. 20: temporal tria 'three times' (A, B, C) (1) imperfectum 3

(A) tempus praeteritum ' 'past time'

(b) praeteritum perfectum4 CANTAVI 24

(c) plusquamperf
(d) [aoristus]? $\begin{array}{ll}\text { CANTAVERAM } & 2 \\ \text { CANTAVI } & 2\end{array}$

(B) tempus praesenss 'present time'

(a) praesens imperfectum 3 CANTO
(b) praesens perfectum4

(d) [aoristus]

[CANTO

24

(C) tempus futurum ' future time'

(a)

(b) futurum perfectum 4

$\begin{array}{ll}\text { CANTEVERO } & 2 \\ \text { CANTABO } & 1\end{array}$

(d) futurum imperfectum 3 .

1 translates chrónoi

3 translates paratatikós

4 translates téleios

5 translates parelēlythós

8 translates enestós
9 translates méllón

6 transiates hypersyntelikós
Three times (A, B, C)

(1) no terminal implied

(A) passato

(a) imperfetto

(d) pluperfetto

$\begin{array}{ll}\text { cantavo } & 1 \\ \text { cantai } & 2 \\ \text { avevo cantato } & 2 \\ \text { cantai } & \end{array}$

(B) presente

presente imperfetto canto

(b) presente perfetto ho cant

(d) [aoristo]

[canto

(c) futuro
(a)
(b) futuro perfetto
(c) avrò cantato 2
(d) [aoristo]

1 Answers the question: "What were/are/will be the conditions, the circumstances?" 2 Answers the question: "What happened? What
happened next?" 
translations, by way of intermediate Latin names, of the Greek ones, and it is therefore no wonder that they no longer fit languages with structures quite different from that of Greek. To make this point, I shall pursue the history of this nomenclature in the following pages.

It must be said, however, that even though well chosen for their meaning, Dionysius' arrangement of the terms into classes leaves something to be desired; it may well be responsible in part for the confusion created by later, non-Greek grammarians.

The division into three classes of "times" (see the Greek portion of my chart) under $\mathbf{A}, \mathbf{B}$, and $\mathbf{C}$ - past, present, future - appears to reflect what the ancients regarded as the cosmic order of things, the ordo rerum of which the Latin grammarian Quintilian says: "Ut sunt autem tria tempora, ita ordo rerum tribus momentis conceptus est: habent enim omnia initium, incrementum, summam." "Just as there are three times, so also the order of things is conceived under three critical points, for all things have beginning, growth, and completion'. ${ }^{16}$

Under $\mathbf{a}, \mathbf{b}, \mathbf{c}, \mathbf{d}$ are given the four 'distinctions', often interpreted by commentators as Aktionsarten, or aspects. However, judging - as one is meant to do - by their Greek names, one finds that they do not really specify the manner in which the event described by the verb takes place (which is what aspects are supposed to do) but rather how the speaker wishes to present to the speaker that action, how the hearer is intended to perceive, to "see" the action'; not objective reality, but the linguistic re-presentation of reality is to be conveyed by the verb. Thus, a, "without regard to terminals", means, not that the action was unfinished, but that the speaker attaches no importance or significance to informing the hearer whether or not the action was in fact finished in the past; and d, "indeterminate for the passage of time" does not mean that the action had no duration ("punctualness" as opposed to duration is often cited as characteristic of the aorist), which would be a physical impossibility, but merely that reference to the passage of time required for the action to take place, be it long or short, is irrelevant to speaker and hearer.

Unfortunately, a, b, c, d are not logically defensible subclasses of the classes A, B, C since they are not defined by compatible criteria, hence do not constitute mutually exclusive sets. One cannot, for example, within the class "table" set up the subclasses "round tables," "square tables," and "small tables" because once shape has been established as the distinguishing criterion of the classification, a subclass whose distinctive property is size is inadmissible. Hence if $\mathbf{a}, \mathbf{b}, \mathbf{c}$ are subclasses defined by reference to terminals, $\mathbf{d}$, which has nothing to do with terminals, cannot belong to the same order of subclasses. (Note that the bracketed aorist in present time, under $\mathbf{B}$, rendered by the present tense livo. illustrates the fact that the present tense can also be aóristos, that is, indeterminate as regards 
passage of time. But normally the term aorist is attached to the past time and names a past tense.)

Realizing that $\mathbf{d}$ was not a subclass of the same order as $\mathbf{a}, \mathbf{b}, \mathbf{c}$ in Dionysius' scheme, the Stoic grammarians, of the first century B.C., while retaining the three times $\mathbf{A}, \mathbf{B}, \mathbf{C}$, thought it appropriate to create an a priori subdivision of tenses into those which were "determinate for the passage of time" and those which, like d, were "indeterminate for the passage of time," which I designated I and II, respectively, on my chart; under I there are two subclasses: 1 "without regard to terminals" and 2 "with regard to terminals." But since 1 is both a subclass of $\mathbf{I}$ and subclass $\mathbf{a}$ of $\mathbf{A}$, and since 2 is both a subclass of $\mathbf{I}$ and subclass $\mathbf{b}$ and $\mathbf{c}$ of $\mathbf{A}$, and since moreover II is again subclass $\mathbf{d}$ of $\mathbf{A}$, one cannot call this new arrangement more logical or tidy than that of Dionysius. Clearly, patching and mending are not sufficient repairs.

Nonetheless, despite this lack of orderliness, the names attached to the tenses by both Dionysius and the Stoics do reveal the function of the verb forms that bear them - but always with the proviso, already stated, that the tense forms do not objectively present reality but re-present it, filtered, as it were, by the speaker so as to evoke the desired image in the hearer (though it is of course not excluded that the presented and the re-presented reality are identical). It should be noted, for example, that lélyka, regularly called perfect tense, appears in both $\mathbf{A}$, the past, and B, the present, both times with the label 12 , that is, "determinate for passage of time" and "with regard to terminals". Hence in its meaning "I have loosened (something)' it describes an action terminated in the past and also states the fact that whatever I have loosened is now in a condition of loosedness. It is from this function of the so-called perfect in Greek that the notion of "perfect" in various other languages derives its alleged property of designating "an action completed in the past whose results relate it to the present". But since these other languages do not have the same number of morphologically distinct past tenses as has Greek, it follows that their past tenses, even if one or the other goes by the same name (e.g., "perfect"), need not and in fact do not fulfill the same functions in the same way as do the Greek tenses.

Similarly, since the Greek aorist (of the past) is "indeterminate for the passage of time," hence labeled II on the chart, it, too, may be used to convey the notion of completion of the action in the past - but, unlike the perfect, without reference to the present. For example, the present tense bállo means 'I throw'; but the aorist ébalon means 'I threw and hit' (i.e., my throwing has attained its completion); so also present pheúgö 'I flee' and aorist éphygon 'I fled and made good my escape'. ${ }^{17}$ But it is not implied, respectively, that my throwing and hitting has produced the result - e.g., a broken bottle - which my hearer can see or which I want him to "see" in his mind's eye, or that I wish to have my hearer see me as a 
present fugitive; that purpose would in fact be served by the perfect tense: béblèka 'I have thrown and hit (that broken bottle that you can see or imagine)', pépheuga 'I have fled and made good my escape (and here I am, a fugitive)'.

Some scholars believe that the Greek system of tenses presents the partial survival of the Proto-Indo-European verb system, which operated exclusively with "aspects" rather than tenses, that is, with the manner in which an action took place (or better, as I said before, in which the action is to be perceived by the hearer), rather than the time - past, present, future - at which it took place. This is possible, but will be difficult to prove. But if inheritance is involved, not all Indo-European daughter languages show the same degree or kind of survival of these "aspects".

Certainly, as regards Latin, the following statement is accurate and notes an important difference between Greek and Latin: "L'expression de l'aspect est beaucoup moins poussée en latin que dans certaines langues (grec, slave, etc.)." "Il y a donc en latin des marques indubitables d'aspect, comme du reste dans la plupart des langues. Mais, en dehors de la distinction fondamentale entre infectum et perfectum, du reste troublé par les diverses valeurs du parfait latin[N.B.!], il ne s'agit pas là d'une catégorie grammaticale nettement déterminée, dont l'expression soit constante et précise. ... dans ce domaine, l'examen des faits relève moins de la syntaxe que du vocabulaire et de la stylistique" (Ernout and Thomas 1953: 216, 219). 'The expression of aspect is much less salient in Latin than in certain other languages (Greek, Slavic, etc.).' 'There are, then, in Latin indubitable traces of aspect, as there are in most languages. But apart from the basic distinction between infectum and perfectum, obscured in any event by the varied values of the Latin perfect [N.B.!], one is not dealing here with a distinctly determined grammatical category whose expression is consistent and precise. ... in this domain, an analysis of the data pertains less to syntax than to the lexicon and stylistics.' Consequently, the Latin imperfect is listed under infectum, the perfect under perfectum. Unfortunately, however, the authors do not resist the temptation to describe the employment of these tenses in terms of duration, completion, extension to the present, etc. - as do numerous other descriptions and textbooks for learners of Latin.

The Romans were proud of their enormous martial and political power, and of their conquests, including that of Greece in the middle of the second century B.C. And Vergil felt that the worldly mission of Rome was "to rule the nations, crown peace with law, spare the humble, tame the proud," leaving the arts and sciences to others better equipped. ${ }^{18}$ But Greece, though vanquished, enthralled the Romans, and Horace had to admit

Graecia capta ferum uictorem cepit et artes intulit agresti Latio. 'Captured Greece captivated her rough conqueror and brought the arts to rude Latium'. 19 
Among these arts was also the study of literature, which gave rise to the Romans' concern for their language. But it was no wonder that the grammarians (many of whom were Greeks to begin with, especially the tutors in charge of students), in attempting to describe the language of Rome and to set standards for the correct and aesthetically satisfying use of it, turned to their Greek predecessors as models. In doing so, however, they not only adopted but at times also mistranslated or misunderstood Greek grammatical terminology. Moreover, they aimed for a description that made Latin appear a very close relative of Greek (which typologically it is not), hoping that thereby some of the glory of Greek letters would rub off on the Latin idiom and its literature. ${ }^{20}$ But this simple transfer of terms to an alien idiom could not but entail distortion and misstatement.

Latin, as noted, has not three past tenses like Greek but only two. The one which Latin grammarians call imperfectum, meaning literally 'unfinished', derives its name from paratatikos, which, however, may mean only that the verb invites the hearer to perceive the action without regard to terminals and does not necessarily imply that the action remained unfinished in reality. Hence, the notion that the Latin imperfectum must signal an action that is actually incomplete in the past rests upon a mistranslation or at least misinterpretation of paratatikós. As regards the Latin perfectum, it had to take on the function of the other two past tenses of Greek, the perfect and the aorist. Its Latin name, however, is derived only from those Greek terms - parakeimenos (A b in Dionysius), hōrisménos and téleios (A I 2 and B I 2 in the Stoics) - which say that the form is intended to convey to the hearer determinacy of time, a terminal (completion), and some involvement of the results of the action with the present; nothing in the name points to the aoristic nature (A d in Dionysius, A II d in the Stoics) which that Latin term clearly possesses. If, therefore, the Latin perfect is in deference to its name characterized as perfectum 'finished' in contrast to some other tenses that are infectum 'unfinished', then only half of its function is captured in the description, namely, the perfective one (as it may be called); but the aoristic one is ignored. A description of the function of the Latin perfect that rests upon its name is as inappropriate as those resting upon such names of tenses as mentioned earlier: passato remoto, passato prossimo, passé défini, passé indéfini, etc. Hence, if the name perfect is to be retained (and there is no important reason why it should not) its function must be stated in different ways.

Varro, after a morphological analysis in which he distinguishes what we now call tenses of the present stem (imperfect tundebam, present tundo, future tundam) and of the past stem (pluperfect tutuderam, perfect tutudi, future perfect tutudero), proceeds to the "logical," analysis of the verb. In this he lists four parts (partes): tenses (tempora), persons (personae), kinds (genera), and distinctions (diuisiones). Among these names, tempora translates chrónoi $(\mathbf{A}$ - praeteritum, B - praesens, 
C - futurum), and diuisiones translates diaphórai (1 - imperfectum, 2 perfectum). I have already commented on the infelicitous Latin names of 1 and 2 , and on the impossibility of causing these two to correspond to the four subclasses - a, b, c, d, - of Greek. But Varro's scheme allows him to align the present stem forms with the aspectual imperfecta, which are, then, imperfect, present, and future, and the past stem forms with the aspectual perfecta, which are, then, pluperfect, perfect, and future perfect: thus morphological paradigms are made to match functional ("aspectual") classes. ${ }^{21}$ However - and this is important - this transfer of Greek terminology and functions to the differently structured system of Latin past tenses produces a skewness which necessitates the appearance of the perfect cantaui in three places on my chart: under $\mathbf{A b}$ as the praeteritum perfectum, where it functions like the Greek perfect; under Ad where, though lacking a special Latin name, it functions like the Greek aorist; and under $\mathbf{B b}$ as the praesens perfectum, which, like the Greek perfect in the same slot, invites the reader to see the result of the action somehow related to the present. Furthermore, the listing of the present tense canto under Bd as the "aorist of the present", like that of lýo on the Greek chart in the same slot, conveys the notion that the present tense also can be aoristos in the sense that it asks the hearer to ignore the passage of time. All this, one must admit, does not make for a very neat schema for Latin, a shortcoming that is clearly due to the attempt of pouring Latin semantic and syntactic functions into a Greek terminological and morphological mould - which was less than ideally suited for Greek itself. ${ }^{22}$

This obliquity was recognized by various modern linguists who tried to put patches on the ancient grammars, but whose repairs were probably not radical enough. I have already mentioned Emout and Thomas' remarks on the disparity between Greek and Latin with respect to aspectual use of the tenses. Allen and Greenough's school grammar teaches that the "perfect denotes an action either as now completed (Perfect Definite), or as having taken place at some undefined point of past time (Historical or Aoristic Perfect)", to which they then add other functions of the perfect, including its use for "general truth, especially with negatives (Gnomic Perfect)" (Greenough 1916: 298-9). The first of these fits into positions $\mathbf{A b}$ and $\mathbf{B b}$, the other into $\mathbf{A d}$. Moore also assigns two separate functions to the perfect, which "represents an action done in past time. As contrasted with the imperfect, it denotes, like the Greek aorist, a single act . . ; as opposed to the present it denotes that the action is already completed ...; [it is] gnomic in generalizations" (Moore 1954: 307-8). This is approximately the same view as Allen and Greenough's. Similar also is Palmer's opinion that the perfect indicative as aorist "refers to the event as an item of history without further qualification, regardless of its actual duration. ... A gnomic use appears already in Plautus ... but this native growth was much stimulated by the example of Greek [N.B.]... The present perfect 
denotes the state resulting from an action" (Palmer 1954: 307-8).

I shall henceforth use the adjective aoristic and perfective to characterize, respectively, the perfect as aorist (lines $\mathbf{A b}$ and $\mathbf{A d}$ on the Latin chart) and the present perfect (line Bb). Typically, certain Latin verbs that occur only in the past stem have this perfective connotation and are translatable by a present tense in English: odi 'I have come to hate' = 'I hate'; noui 'I have become acquainted' = 'I know'; consueui 'I have acquired the habit' = 'I am accustomed'; memini 'I have stored in my memory' = 'I remember'. Conversely, the non-perfective meaning is expressed by the so-called inceptive or inchoative verbs (poorly named since they do not denote merely the beginning of an action but rather its being in progress) which are characterized by the infix -sc-: nosco 'I become acquainted' (at times given the same meaning as noui); consuesco 'I accustom myself' (at times given the same meaning as consueui), also used transitively 'I accustom (someone to something)'; reminiscor 'I recall to mind' (at times given the same meaning as memini); calesco 'I grow warm'; irascor 'I get angry'; etc. This type of verbs would fit under the heading of praesens imperfectum (line Ba).

One concludes that, if the Latin system of past tenses is not, indeed cannot be, entirely congruent with the Greek system, the two tenses it comprises imperfect and perfect (I am omitting again the relative pasts, pluperfect and future perfect) - do indeed fulfill certain so-called aspectual in addition to, or sometimes in the place of, temporal functions.

In the following few examples it is idle to wonder whether the same lexical Latin verb expresses in all three phrases the same reality, or whether the different tenses depict different realities; both are possible, depending on the verb and the tense used. But the main point I wish to make (and have made above, and will make again in my conclusion) is that the different tenses evoke in the hearer, and are used for this purpose by the speaker, different views of reality. To make these views explicit in my translations, I have taken the liberty of using different verbs for the Latin verb (e.g., 'I was ambling - I walked - I went', all translating forms of ire) or different constructions of the same English verb (e.g., 'they were in hiding - they went into hiding - they have hidden', all translating se occultare).

Imperfect

se occultabant

'they were in hiding'

ibam [forte Via sacra sicut meus est mos] ${ }^{23}$ 'I was ambling along [the Via Sacra, as is my wont]
Perfect

aor: 'they went into hiding'

se occultauerunt

perf: 'they have hidden (and are hidden)'

aor: 'I walked'

ii

perf: 'I went (and arrived)' 


\section{eram hodie ad funus 'I was present today at a funeral'}

saepe dicebam 'I often said' 25

haec mihi fere in mentem ueniebant ${ }^{26}$ 'this is about what would come to my mind' fui hodie in funus ${ }^{24}$

aor: 'I went to a funeral today"

perf: 'I went to (and arrived at) a funeral today'

aor: 'I often said'

saepe dixi

haec mihi fere in mentem uenerunt perf: 'I have of ten said (and am still saying)'

aor: 'this is about what came to my mind'

perf: 'this is about what has come to (and now is in) my mind'

Thus, the imperfect emerges as the tense which invites the hearer to see an action as background, as a circumstance or a condition, including repetitive and habitual actions (which may be regarded as circumstantial); the aoristic perfect seeks to have the hearer see actions in a narrative sequence of events; and the perfective perfect wants the hearer to perceive the relation of a past action with the present. Note that the aoristic and the perfective perfect are expressed by the same form in Latin, the perfect tense, which is a bit untidy and makes one or the other interpretation dependent upon context, or possibly leaves the hearer with a choice of interpretation. (The Greek system, having three past tenses, was neater in this respect.)

Let us now, after this historical excursus, return to Italian and French. Of the three past tenses, the imperfetto/imparfait and the passato semplice/passe simple are direct morphological continuations of the Latin imperfect and perfect, respectively:

imp. cantabam $>$ cantavo, (je) chantais

perf. cantaui $>$ cantai. (je) chantai

But the third, passato composto/passé composé, has no morphological antecedents, at least not in Classical Latin, and not in the active voice; but phrases of the type habeo litteras scriptas 'I have a letter (that has been) written', or 'I have a written letter' do occur in colloquial Latin before and during the classical period; they end up meaning 'I have written a letter' and retain the perfective connotation of referring to a letter that has been written and is now to be viewed by the hearer in a written condition, as it were. (Since scriptas was originally used adjectivally, it agreed with litteras; but with habere becoming an auxiliary verb and the original 
adjectivally used participle becoming the participial portion of a compounded tense, the result is that in Italian and French that participial portion, forming a syntactic unit with the auxiliary verb rather than with the noun, does not agree morphologically with the noun: ho scritto (not scritta) una lettera, j'ai écrit (not écrite) une lettre; but if one still can find ho scritta una lettera in Modern Italian, the construct, learned and recalling a Latin long since gone, sounds archaic; French j'ai écrite une lettre is, however, impossible. The rise and spread of this active compounded past tense is one of the hallmarks of the Romance languages, though it does enjoy a remarkable success also in other Indo-European languages.)

It is not surprising that the passato semplice/passé simple should continue both the aoristic and the perfective functions of the Latin perfect, and the imperfetto/imparfait those of the Latin imperfect. But the availability of the compounded past allows one of the two uses of the simple past to devolve upon it; and in view of the origin and evolution of the compounded past briefly stated in the preceding paragraph, it seems obvious that it should acquire the functions of the perfective perfect. One might, then, expect a tripartite division of functions - imperfetto/imparfait, perfetto semplice/passé simple, perfetto composto/passé composé - matching exactly, though not by inheritance but by accident, that of Greek - imperfect (Aa), aorist (Ad), perfect (Ab and Bb). But, not surprisingly, things did not turn out quite so simple and logical.

First of all, as regards Italy in particular, there are those dialects of the north mentioned earlier, which do not have a simple past at all, and in which the compounded past bears both the aoristic and the perfective burden; second, there are those dialects of the south, also mentioned, which largely ignore, and sometimes just do not possess, the compounded past and in which the simple past bears both the aoristic and the perfective burden. This leaves the dialects of the center, including Tuscan and with it Standard Italian, where the simple and the compounded past are approaching, and in some places have already attained, free variation, though a stylistic distinction assigns greater prestige and formality to the simple past, while the compounded past acquires ever wider currency in colloquial Standard Italian. But the name passato prossimo for the passato composto does recall the perfective function of that tense as inherited from the habeo litteras scriptas type of construction; and in contrast to it the name passato remoto was devised for the passato semplice, a name meant to indicate, albeit somewhat obliquely, the aoristic function of that tense. It appears, then, that Italian was on the way to a reasonable threefold functional distinction of its past tenses - imperfective, aoristic, and perfective that matched a morphological one - imperfetto, passato semplice, passato composto. What with the northern and southern dialects rejecting one or the other of the two non-imperfect tenses, and Tuscan together with the standard language not adhering to the triple distinction but allowing matters of style and prestige to muddy the 
scheme, the analyst and teacher of Modern Standard Italian is now faced with the difficulties that I described at the beginning of this article - IF he persists in seeking the truth in the names for these past tenses, and IF he does not manage to free himself from a phrasing of rules that are hoary and creaking with age.

If one looks back now upon the directions of many grammarians for the employment of the past tenses of Italian that I discussed at the beginning, one realizes that their phrasing and content is based upon the aspectual theories of the Latin grammarians. But these had, in fact, rather thoughtlessly appropriated the analysis and terminology of their Greek tutors, which more or less - though far from ideally - fitted Greek, but were unsuitable for Latin. And since most Italian grammarians were equally uncritical vis-à-vis their Latin precursors, Italian, and also the other Romance languages, indeed many other Indo-European tongues, came to have their tenses described in terms, increasingly less suitable with the passing of time, of the aspectual system of Greek. A number of perceptive scholars have tried to mend and amend those rules; but their revisions were not radical enough. After all, since we have learned that Latin and the Romance languages differ typologically in their structure despite their genetic relationship, there is no cause or need to persist in using the Latin - or rather, Greek - model of verbal aspects, even if applied loosely or modified, in the analysis and description of Italian and other Romance and non-Romance languages.

The problem is now to determine what exactly the past tenses in Italian (and other languages) do signal nowadays, and how to phrase instructions for their use in the simplest possible manner. It was pointed out earlier that the sentences Dio creava/creò/ha creato il mondo refer, despite the variety of tenses, to a single and unique event. Since, therefore, all three tenses describe the same action, the question is just what causes the speaker to select, at a given occasion, one tense rather than another, and just what the hearer comprehends, or is intended to comprehend, on the basis of that selection. And the simplest way I have discovered to account for the choice, which I have tested myself, and had tested by students and teachers, is to regard each of the three tenses as answering a specific question, either actually posed or implied. Here are the rules, then, for the use of the past tenses in Italian - which, I believe, derive their validity from the preceding historical discussion that reaches all the way back to the Classical Greek language and the Greek grammarians.

(1) IMPERFETTO. This tense is used when the posed or implied question is: "What were the circumstances, the conditions? What was going on?" Accordingly creava invites the hearer to be an eyewitness, as it were, to God's labors. (See p. 247, above.) It says "There is God busy with creation, look at him as he does this - a long time ago." Whether these labors were ever terminated or not is implicitly of no concern to hearer or speaker. It is therefore not true, most 
egregiously not as regards the creation of the world, that the imperfetto describes literally an imperfectum, something unfinished. By the same token, Giovanni andava alla spiaggia ogni giomo 'Giovanni went (would go) to the beach every day' also speaks, not of an event or a series of events, but of circumstances, condjtions, of a background against which an event may take place that is possibly but not necessarily stated in another sentence in the same text. To be sure, andava here speaks of a repeated, habitual action; but this is not a distinctive characteristic of the imperfetto since Giovanni andava alla spiaggia may refer to a single going to the beach by Giovanni, with the imperfetto merely serving to put the hearer into the picture, observing Giovanni as he walks, so to speak: that still comes under the heading of background, situation, circumstances. Of course, the same going to the same beach by the same Giovanni on the same day could also be reported by means of the passato semplice, but in answer to another question: see below, (2a). ${ }^{27}$

(2) (a) PASSATO SEMPLICE. This tense is used when the posed or implied question is: "What happened? What happened next?" Accordingly, creò reports a past event within a narration. Other events so described may but need not occur in the same sentence or in the same text.

(b) In local or social dialects where the compounded past replaces the simple past, either in free variation or to the exclusion of the former, ha creato in its aoristic use answers the same question.

(3) PASSATO COMPOSTO. This tense is used when the posed or implied question is: "What has happened?" (In contrasting the question "What happened?" in (2) with "What has happened?" in (3), I am taking advantage of the peculiarity of English usage, where the former is aoristic and the latter perfective: cf. I wrote a letter vs. I have written a letter, exactly as in Italian scrissi una lettera vs. ho scritto una lettera - with the proviso, however, that the latter Italian form be intended and comprehended as perfective rather than aoristic as in (2b) above.) Accordingly, ha creato is meant to say to the hearer that the creation took place in the past but that its results in some way relate it to the present. ${ }^{28}$

Since, according to the above scheme, the compounded past can be used in both the aoristic and the perfective sense, Italian has, like Latin with its perfectum, a tense whose intended function is conveyed not by morphology but by the context. There seems to have been a period, between Latin and Modern Italian, when the ambiguous nature of the Latin perfectum was repaired by the rise of the compounded past, which took on the perfective meaning of the perfectum, while the aoristic meaning remained with its morphological continuation, the simple past. But this agreeable arrangement was put in jeopardy by the rise of the compounded past as the functional equivalent of the simple past. One must conclude (and anyone with a feeling for historical linguistics knows this) that even if certain observable 
changes appear to be capable of moving the language in the direction of greater clarity and logic, speakers will not necessarily avail themselves of these admirable possibilities. Language is not designed, it just grows; and over the six-thousand years for which we have linguistic records, no improvement or progress can be discerned.

The set of rules proposed above for Italian can be in toto transferred to Modern French: Dieu créait/créa/a créé le monde; Jean allait/alla/est allè à l'école /chaque jour); j'écrivais/j'écrivis/j'ai écrit une lettre - all these are constructed and can be explained in accordance with the specific questions posited for Italian. One might perhaps add that in Modern Standard French the difference between the simple past (passe simple) and the compounded past (passé composé) is more of a stylistic and less of a regional or social order than it is in Italian. And the expanding replacement of the simple by the compounded past, which adds to the latter's perfective the aoristic function, brings about the same problems in French as it does in Italian. ${ }^{29}$

What with the simple and compounded pasts in ebbi/ho avuto una lettera, j'eus/j'ai eu une lettre all being able to answer aoristically the question "What happened?", these sentences may be translated 'I received a letter'; of course, the pertinent forms of the verb 'to receive' - ricevei/ho ricevuto, je reçus/j'ai reçu render exactly the same meaning. (Note that English $I$ had a letter can serve the same aoristic purpose.) In contrast, avevo una lettera, j'avais une lettre, answering the question "What were the circumstances?", mean 'I had (had in my possession) a letter'. (Here, English had is not aoristic.) In the same way, fui/sono stato ammalato, je fus/i'ai été malade mean 'I became sick' - as do mi ammalai/mi sono ammalato, je tombai/je suis tombé malade - whereas era ammalato, j'étais malade report the condition 'I was sick'. (Note that English was can be, but is less likely to be, used aoristically; got, became, fell will be used in preference to was.)

The characteristic tasks of the Italian and French imperfect and the two perfects show up even more clearly in the passive voice, where to be as the auxiliary followed by a past participle overlaps and may conflict with to be as copula followed by an adjective, which may also be a past participle. For example, era lodato, il était loue may convey a passive 'he was praised (by someone)' or 'he was (a) praised (man)'. But since fu/è stato lodato, il fut/a été loué cannot state a condition but answer the question "What happened?", they are unmistakably passive - though the English translation is still 'He was praised (by someone)'.

Thus, the Italian imperfetto era followed by a past participle carries a double load: it is either auxiliary for the passive voice or copula. English was, however, carries a triple load: it is auxiliary or copula, as in Italian, but it also has the aoristic function which Italian expresses by either the simple or the compounded past of essere 'to be'. To express passiveness more clearly, Italian has come to use 
venire 'to come' (with some verbs, and less frequently, stare 'to stand': but see below, fn. 30) as an alternate auxiliary, hence veniva lodato 'he was praised'. But English, too, often uses an suxiliary other than to be for emphasizing passiveness, namely, to get. Hence, the last Italian example may well be translated as "he got praised', which precludes the adjectival sense inherent in 'he was praised', i.e., 'he was a praised man'. These new auxiliaries of the passive voice can of course occur in non-past tenses: viene/verrà lodato, he gets/will get praised. But although, as stated, fu/è stato lodato, answering the question "What happened?", are already unmistakably passive, the simple past of venire can also be used for the same meaning: venne lodato 'he got praised'. (But in this construct, the passato composto

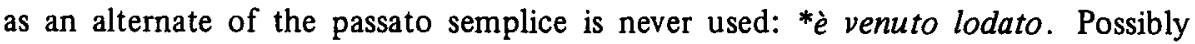
this composition is shunned because $\dot{e}$ venuto might be heard as the compounded past of venire 'he has come', which leaves lodato dangling senselessly at the end.) In French, however, no evidence can be discovered at the present time for the rise of an auxiliary for the passive in place of, or alternating with, être 'to be'. ${ }^{30}$

I shall not attempt to extend my view on the use of past tenses to other Romance languages, which I do not know as well as I know Italian and French (a restraint that applies a fortiori to numerous other languages of the world). And it would serve no fruitful purpose if I were to ransack the descriptions and grammars of such languages in search of the rules that I objected to in the traditional Italian grammars and textbooks. But I hope that my thesis may cause linguists and philologists - and not only Latin-Romanists - to re-examine the use of tenses in languages of which they have a native or near-native competence, and to forsake the Graeco-Latin prejudice and terminology with which we have allowed ourselves to be burdened.

\section{NOTES}

1. One may call this the syntagmatic dimension of tenses, as distinguished from the paradigmatic one, which lists and names them: cf. Weinrich (1977: 9-10); naturally, Weinrich's interest in textlinguistics emphasizes the syntagmatic dimension.

2. Two important exceptions must be noted. One is Weinrich (1977) which offers an entirely new and fresh view emerging from the author's concern with textlinguistics (see above, fn. 1); the other is Joos (1964). (See the discussion of Joos (1964) in Weinrich (1977: 311-5) under the title: Eine Koinzidenz.) Because of our different approaches and aims, I have no occasion to quote either Weinrich or Joos at length; but I have gained much stimulation from both.

3. I shall mostly refrain from translating into English both the names of the tenses and the verb forms themselves, except where translation is germane to my 
argument and can be performed without distorting the meaning. Hence, I shall on occasion use the morphologically appropriate terms simple past for the passato remoto, and compounded past for the passato prossimo.

4. Rohlfs (1969: 44) notes that the imperfetto may also be used to express a nonreality, as in quasi cadevo 'I almost fell (but did not)', which leads on to per poco moriva (= mancò poco che morisse) 'he almost died (= it lacked little and he would have died)' (the second reminds one of southern American he liked (actually lacked?) to have died, and indeed of French il a manque de mourir); the next step in Italian then is doveva partire $=$ avrebbe dovuto partire the ought to have left (but did not)', and se tu non venivi, ti cercavo = se tu non fossi venuto, ti avrei cercato 'if you had not come (but you did) I would have looked for you (but did not)'. Rohlfs connects such locutions with the Latin imperfectum de conatu 'imperfect of attempt', as in dicebat 'he tried to say (but could not)'. And finally, the imperfetto may also substitute for a conditional ("future of the past"), as in si allontano dicendo che tornava (= tornerebbe, sarebbe tornato) subito 'he went away saying that he would return at once (but he has not returned yet)'. But these uses of the imperfetto have little to do with aspectual function. Nor are they a peculiarly Italian invention; one finds even in Cicero's Latin si licitum esset ueniebant (rather than the subjunctive uenirent; Cicero, Verr. 5.129) 'if it were permitted, they would come'. On the use of the past indicative in contrary-to-fact conditional clauses in other languages - Eng. if I was (= were, but I am not), French si j'étais (mais je ne suis pas) - see Pulgram 1983 (also in Pulgram 1984, No. 36), where an explanation from redundancy is proposed: in if $I$ was the past tense refers to present time, hence signals something other than if $I \mathrm{am}$, whereas in if I were two features, past tense and subjunctive, deliver a redundant signal.

5. The same notion appears also in Agard and Di Pietro (1965: 69-70) who say that "the choice [between imperfetto and passato remoto] is ultimately of a lexical order" - although the lexical difference may appear in the translation rather than in Italian: lo sapeva 'he knew it (= possessed the knowledge)' - lo seppe 'he knew it (= found out, learned)'.

6. Since the following directions could occur in any number of textbooks, albeit differently worded, it would serve no useful purpose to give an exact bibliographical reference.

7. "Chi vuole spiegare il funzionamento di un livello sincronico, deve comparare sottosistemi coesistenti'" Muljačić (1971: 128). 'Whoever wants to explain the functioning of a synchronic level must compare coexistent subsystems.'

8. See, for example, Hall (1971: 164); Rohlfs (1969: 43-9); Migliorini (1948: 128); Lepschy and Lepschy (1977: 220).

9. See Pulgram 1963 (also in Pulgram 1984, No. 33). 
10. Cf. Rohlfs (1972: 315). Migliorini (1948: 128) remarks that "gli Italiani del Settentrione usano forse troppo parcamente del passato remoto, mentre gli Italiani del Mezzogiomo ne abusano." '.. the Italians of the north use the passato remoto perhaps too sparingly, whereas the Italians of the south overuse it.'

11. See Rohlfs (1972: 258-61, 306-17, 341) and in other works by the same scholar, who is without doubt the best authority on southern dialects in general and on the "Greekness" of the south in particular.

12. Muljačić (1971: 127): "Nell'epoca presente l'italiano standard è esposto a una stoscanizzazione sempre più forte che ne intacca tutti i sottosistemi, sopratutto quello lessicale. Gli effetti di tali tendenze 'italianizzatrici' sono più sentiti più ci allontaniamo dallo spazio linguistico toscano. La base dell'italiano standard diventerà forse un giorno quell' 'italiano senza aggettivi' . . che, per il momento, si sta appena formando." "At the present time, Standard Italian is subjected to an ever stronger de-Tuscanization which is affecting all subsystems, especially the lexical one. The effect of these "italianizing" tendencies is felt the stronger the farther we move away from the Tuscan linguistic area. The basis of Standard Italian will perhaps, one day, be that "Italian without adjectives" ... which, for the moment, is just barely in the process of formation'.

13. It is interesting to note that in Modern German, too, northern and southern regional standard speeches diverge in the use of the two (not, as in Italian, three) past tenses available, the non-compounded (preterite, imperfect, or Mitvergangenheit, as, for some peculiar reason, my school grammars used to name it) and the compounded (perfect, or Vergangenheit, so called for no better reason). In the south - Bavaria, Austria - the non-compounded is scarcely used; in the north, a distinction is still made between the two, but it depends more often on the lexicon than on the reality to be described. The greater prestige, however, attaches to the northern usage, no doubt because Modern Standard German does not rest upon southern speech - any more than Standard Italian rests upon the Neapolitan dialect. Since I grew up as a speaker of Southern German, bidialectal in the Viennese dialect and the regional standard, I had to be taught in school to use, when speaking or writing very formally, the form ich ass rather than ich habe gegessen (essen 'to eat') - which, given the considerable morphological distance between the two in many verbs, took some learning and getting used to. In the German-speaking countries, too, local and social dialect criteria are intermingled, often inextricably, except that, unlike in Italy, the south is not regarded with derogation or condescension by the Northerners (not by all of them, anyhow).

14. The recent (1932) Grammaire de l'Académie française (no author named), 
admittedly a work useless to the point of silliness, acknowledges that the simple past is being widely replaced by the compounded past but cannot refrain from regretting that some modern writers are, as they follow this trend, giving up a useful distinction - which is, according to the Grammaire's definitions, the one proclaimed by Italian grammarians, i.e., completion versus incompletion, distant versus near past, etc. (cf. Grammaire, p. 170).

15. It should be borne in mind that both the Greek and Latin terms for 'grammar' and 'grammarian', derived from the Greek graphein to write', had, despite the narrowness of their etymon, a much wider meaning than the modern 'grammar'; they referred to philology in general, including literary criticism. No doubt this is due to the conviction, common in antiquity but not altogether alien to some modern grammarians and amateur linguists, that what is written represents the best way of using a language and, therefore, constitutes the model from which grammarians must derive their rules.

16. Quintilian, Inst. or. 5.10.71. Unlike English, which distinguishes natural times and grammatical tenses, Greek and Latin, and many modern languages, have but one term for both concepts. No doubt this lexical peculiarity has some repercussions in the connection between the verb and the "order of things" as stated by Quintilian. In my translations, I use 'time' if both time and tense are implied by the original; elsewhere, I use whichever of the two terms that renders the intended meaning.

17. The two verbs here cited have the so-called second aorist, or root aorist, which lacks the sigma characteristic of the other more frequent type of aorist, as in élysa on the chart.

18. Vergil, Aeneis 6.847-851.

19. Horace, Epistulae 2.1.156.

20. For details on the relation between Greece and Rome as regards literature and grammatical works, see Pulgram (1975: 28-35).

21. Varro, De lingua latina $8.20,9.95,10.48$. The most famous and most influential Latin grammarians for the Middle Ages, and indeed thereafter, were Aelius Donatus, of the fourth century A.D. (among whose pupils was the future St. Jerome, 348.420, author of the Latin version of the Bible, the Vulgate), and Priscianus, of the sixth century.

22. In the same way, and with even less satisfactory results, the first describers of American Indian languages, who were mostly clerics wishing to preach the Gospel in the native idioms, composed descriptions of those tongues in the completely inappropriate terms of Latin grammar.

23. Horace, Satirae 1.9.1.

24. Petronius, Satyricon 20. It should be noted that in Modern Spanish the derivatives of the perfect fui, etc. are the only forms for the simple past tense of ir 
'to go': fui a los funerales 'I went to the funeral'. Cf. also French il s'en fut 'he made off, ran away'. More about such uses of the simple past in Romance will be said later.

25. The imperfect phrase could have been translated 'I would often say', where English would, even without often, intends to convey a condition, a state of habitual saying; the aoristic perfect wishes the hearer to see these repeated actions as recurring in a series, one after the other; the perfective aorist wishes the hearer to get the notion that the frequent saying (of something) has some relation to the present, which is conveniently expressed in English by using the compounded past.

26. Cicero, De deorum natura 2.67.168. Allen and Greenough quote the Ciceronian phrase in the imperfect and translate it 'that is about what occurred to me' - not felicitously, I believe, since that wording does not create a contrast with the aoristic perfect phrase uenerunt. In fact, they add this note: "[In a straightforward narration this would be uenerunt.]" (Greenough 1916, 297). But with this remark they come close to my thesis that it is not objective reality itself that determines the use of tenses but the manner in which reality is to be re-presented.

27. An interesting observation is made in Lepschy and Lepschy (1977: 222-3): "[The imperfect can also be used] instead of the past historic [= passato semplice] in narrative ('the historical imperfect'), originally to give a loftier, epic tone; but this has been so overworked in newspaper reporting that now it also has a journalistic connotation: here is an example from the daily Il Giomo (24 August 1974): 'Il bandito si avvicinaVA alla Brembilla intimidandole di aprire $i$ cassetti della sua scrivania e qui rinveniVA circa 800 mila lire, che infilaVA in un sacchetto di plastica. Subito dopo i due rapinatori usciVANO di corsa bolzando su una motocicletta, ma nell'andarsene ad uno degli sconosciuti sfuggiVA di mano il casco ed il passamontagna'. [Capitals for imperfect endings added.] 'The robber went up to Miss (or Mrs.) Brembilla and ordered her to open the drawers of her desk; here he found about 800,000 lire, which he slipped into a plastic bag. Immediately afterwards the two robbers ran out, leaping onto a motorcycle, but as they went out one of the two unknown (persons) lost hold of his helmet and balaclava'." It seems to me that what this journalist - and others who follow the same pattem - seeks to do, by using the imperfect rather than the aoristic simple (or compounded) past, is to induce the reader to see the action as if he were actually observing it in its progress, or viewing it on film, in other words, to involve the reader in the activity, as it were, rather than present him with a narration of things past and done with. Rather than "historical imperfect" I should be inclined to call it (if a name be needed) "dramatic imperfect". Indeed, to dramatize, to involve 
the hearer or reader in the event rather than put it before him cut and dried, is an effect that the imperfect in particular can achieve. The same result can be obtained, for the present time, by the present tense, which, like the imperfect, is indeterminate with regard to terminals (paratatikós in Greek grammatical terms) by merely asking the hearer to watch an action in its progress, and which, if it is used to speak of things that actually happened in the past, takes the place of the imperfect and is called "historical present"; for it, too, "dramatic present" would be a suitable term. This use of the present tense also lies behind such captions on newspaper photographs as: "Yesterday, the President shakes hands with the ambassador of France."

28. I did find the device of asking questions in a textbook for beginning students of Italian; unfortunately, however, the author allowed also reference to completion vs. non-completion of the action to intrude, which is, once the proper question is asked, irrelevant and even confusing. Cf. Lazzarino (1979: 73): "The imperfetto . . . is used to describe . . an action in the past that was not completed. It answers the question: What was going on?" "The passato prossimo [in what I call the aoristic function] is used to report or narrate an event or an action that was completed in the past. It answers the question: What happened?" I am pleased with this - at least partial - convergence. But in Lazzarino (1980: passim), the author reverts ("perhaps unwisely", she writes me upon my inquiry) to traditional rules, foregoing the questions.

Weinrich (1977: passim), proposes two groups of tenses, besprechende Tempora and erzählende Tempora, whose functions are reflected in the subtitle of the book: Besprochene und erzählte Welt. Weinrich's twofold grouping does not coincide with my twofold questions since we start from different criteria and pursue different aims. He assigns, for example, both the imparfait and the passe simple of French to the category of erzählende Tempora, but reserves the former for Hintergrund 'background' and the latter for Vordergrund 'foreground'; since, however, it is impossible to say once and for all what, in a given narration, is background and what foreground, the distribution of imparfait and passe simple is "im Ermessen des Erzählers" 'at the discretion of the narrator' (93). So also in my own scheme this distribution does not flow from reality itself but from the manner in which the speaker wishes to re-present reality. Thus Weinrich and I agree in two fundamental respects: tenses do not necessarily have anything to do with the time (past, present, future) whose name they bear, and tenses (if I may here insert my own terminology without - I hope - distorting Weinrich's intent) do not necessarily present reality but often re-present it.

29. On the history of the use of the passe simple and passé composé see the illuminating remarks in Weinrich (1977: 256-66). 
30. For further details on the passive voice and its auxiliaries see Pulgram (1977) (also in Pulgram 1984, No. 34). In the southern dialects of Italy, essere as a copula can be replaced by stare: sta/stava seduto 'he is/was seated (sits/ sat)', sta/stava contento 'he is/was content' are synonymous with è/era seduto, è/era contento. This reminds one of the derivative of Latin stare in Spanish, estar, which is normally used in the sense of 'to be' to express a temporary quality or state: está sentado 'he is seated', está contento 'he is content'. (The derivative of Latin esse, which in Spanish, by way of Spoken Latin essere, and probably conflated with sedere, is ser, Old Spanish also seer, denotes an inherent quality: el abuelo es viejo 'grandfather is old'.)

\section{REFERENCES}

Agard, Frederick B. and Robert J. Di Pietro

1965 The Grammatical Structures of English and Italian, Chicago: University of Chicago Press.

(Anonymous).

1932 Grammaire de l'Académie française, Paris: Firmin Didot. Bull, William E.

1968 Time, Tense, and the Verb, Berkeley: University of California Press.

De Mauro, Tullio

1970 Storia linguistica dell'Italia unita, Second Edition, Bari: Laterza.

Ernout, Alfred and François Thomas

1953 Syntaxe latine, Paris: Klincksieck.

Greenough, J.B. et al. (eds.)

1916 Allen and Greenough's New Latin Grammar, Boston: Ginn.

Hall, Robert A., Jr.

1971 La struttura dell'italiano, Rome: Armando Armando.

Joos, Martin

1964 The English Verb: Form and Meaning, Second Edition, Madison: University of Wisconsin Press.

Lazzarino, Graziana

1979 Da capo: A Review Grammar, New York: Random House

1980 Prego: An Invitation to Italian, New York: Holt, Rinehart, and Winston

Lepschy, Anna Laura and Giulio Lepschy

1977 The Italian Language Today, London: Hutchinson.

Migliorini, Bruno

1948 Grammatica italiana per la scuola media inferiore, Second Edition, Florence: Le Monnier. 
Moore, R. W.

1934 Comparative Greek and Latin Syntax, London: G. Bell.

Muljačič, Žarko

1971 Introduzione allo studio della lingua italiana, Turin: Einaudi.

Palmer, Leonard R.

1954 The Latin Language, London: Faber and Faber.

Pulgram, Ernst

1963 "Synthetic and Analytic Morphological Constructs," Festschrift ... Alwin Kuhn (= Innsbrucker Beiträge zur Kulturwissenschaft 9/10), pp. 35-42.

1975 Latin-Romance Phonology: Prosodics and Metrics, Munich: Fink.

1977 "Indo-European Passive Paradigms: defects and repairs," Forum Linguisticum 2.95-106.

1983 "The Reduction and Elimination of Redundancy," Essays ... C.F. Hockett, pp. 107-25. Leiden: Brill.

1984 Practicing Linguist: Essays on Language and Languages. Heidelberg: Winter

Rohlfs, Gerhard

1969 Grammatica storica della lingua italiana e dei suoi dialetti, Turin: Einaudi.

1972 Studi e ricerche su lingua e dialetti d'Italia. Florence: Sansoni.

Weinrich, Harald

1977 Tempus. Besprochene und erzählte Welt, Third Edition, Stuttgart: Kohlhammer.

\section{ANCIENT AUTHORS CITED}

Marcus Tullius Cicero, De renum natura; Actio in Verrem

Dionysius Thrax, TEХ

Quintus Horatius Flaccus, Epistulae; Satirae

Petronius Arbiter, Satyricon

Marcus Fabius Quintilianus, Institutio oratoria

Marcus Terentius Varro, De lingua latina

Publius Vergilius Maro, Aeneis 